DOI: $10.34185 / 1991-7848.2018 .01 .03$

УДК 621.891

Ю.Г. Кобрін, І.А. Шевченко, Д.О. Кононов,

Т.О. Васильченко, О.М. Гречаний

\title{
ВИЗНАЧЕННЯ ШВИДКОСТІ ШАРУ МАТЕРІАЛУ В МОЛОТКОВІЙ ДРОБАРЦІ
}

Робочі процеси подрібнення використовуються в різних галузях виробництва. Залежно від якості та властивостей матеріалу, процеси обробки здійснюються подрібнювальними машинами різноманітних конструкцій. Серед них значного поширення набули дробарки ударної дії. Для подрібнення крихких матеріалів, з утворенням продуктово-повітряного шару, використовуються молоткові дробарки. Це пояснюється тим, що молотки хитаючись навколо осей підвісу змінюють свою відносну швидкість, напрямок та глибину занурення в продуктово-повітряному середовищі, що порушує його рівномірний рух. Задача дослідження - знайти залежність середньої швидкості шару подрібнювального матеріалу від швидкості молотків - одного з основних параметрів молоткової дробарки. Розглядаються процеси подрібнення крихких матеріалів, з утворенням продуктовоповітряного шару, дробарками ударної дії у яких ефективність руйнування частинок залежить в основному від їх швидкості відносно молотків і нерухомої поверхні робочої камери. Проведено теоретичні дослідження - пошук залежності середньої швидкості шару подрібнювального матеріалу від швидкості молотків - одного з основних параметрів молоткової дробарки. Надані залежності середньої швидкості шару подрібнювального матеріалу від швидкості молотків дробарки котрі можуть бути застосовані при визначенні конструктивно-технологічних параметрів молоткових дробарок.

Ключові слова: удар, руйнування, швидкість.

\section{Вступ}

Робочі процеси подрібнення використовуються в різних галузях виробництва. Залежно від якості та властивостей матеріалу, процеси обробки здійснюються подрібнювальними машинами різноманітних конструкцій. Серед них значного поширення набули дробарки ударної дії. Для подрібнення крихких матеріалів, з утворенням продуктово-повітряного шару, використовуються молоткові дробарки. Це пояснюється тим, що молотки хитаючись навколо осей підвісу змінюють свою відносну швидкість, напрямок та глибину занурення в продуктовоповітряному середовищі, що порушує його рівномірний рух.

У молоткових дробарках окружна швидкість по кінцях молотків зазвичай становить 35$65 \mathrm{~m} / \mathrm{c}$, іноді вона досягає $115 \mathrm{~m} / \mathrm{c}$. ГОСТом 7090-72 передбачається для кожного типорозміру молоткових дробарок три значення окружних швидкостей: 40, 50 і 65 м/с [1].

Молотковідробарки призначені для крупного, середнього i дрібного дроблення матеріалів зазначених вище властивостей, але найчастіше їх застосовують для середнього і дрібного дроблення. У молоткових дробарках досягається ступінь дроблення до 30-40. Вони характеризуються високою продуктивністю па одиницю маси, питома витрата енергії на подрібнення в них нижче, ніж у щекових, конусних або валкових дробарок [2].

\section{Аналіз досягнень}

В молоткових дробарках частинки крихких матеріалів руйнуються як під ударами молотків, так і в результаті співударяння самих частинок з гранями отворів решета і декі при русі їх шару по циліндричній поверхні. Ефективність руйнування частинок залежить в основному від їх швидкості відносно молотків і нерухомої поверхні робочої камери. Простежити рух окремої частинки дуже складно, тому оперують середньою швидкістю шару, яка за абсолютною величиною менша за лінійну швидкість кінців молотків [3,4].

(c) Кобрін Ю.Г., Шевченко І.А., Кононов Д.О., Васильченко Т.О., Гречаний О.М., 2018 


\section{Постановка завдання}

Задача теоретичного дослідження - знайти залежність середньої швидкості шару подрібнювального матеріалу від швидкості молотків - одного 3 основних параметрів молоткової дробарки.

\section{Головна частина досліджень}

В молоткових дробарках переважає руйнування в результаті вільного удару. Куски сировини, що подаються в молоткову дробарку зазнають удари шарнірно підвішених до обертаючогося ротора молотків. В процесі подрібнення частинки матеріалу відкидаються на відбійні плити, співударяються між собою, знову відскакують до молотків. Під час роботи на циліндричній поверхні камери дроблення утворюється шар частинок подрібнювального матеріалу. Молотки переміщуються в цьому шарі, руйнують частки матеріалу і примушують їх рухатися під дією сили опору переміщенню молотків в шарі подрібнювального матеріалу (рис.1) [2,5].

Рушійна сила:

$$
F=\varepsilon S_{p} \rho \frac{\left(V_{p}-V_{s}\right)^{2}}{2},
$$

де $\quad \varepsilon$ - коефіцієнт опору або пропорційності (аналог коефіцієнту тертя);

$S_{p}$ - лобова площа частини молотків, яка занурена в шар матеріалу, $\mathrm{M}^{2}$;

$\rho$ - щільність шару, кг $/ \mathrm{M}^{2}$;

$V_{p}$ - лінійна швидкість кінців молотків, м/с;

$V_{s}$ - швидкість шару, м/с.

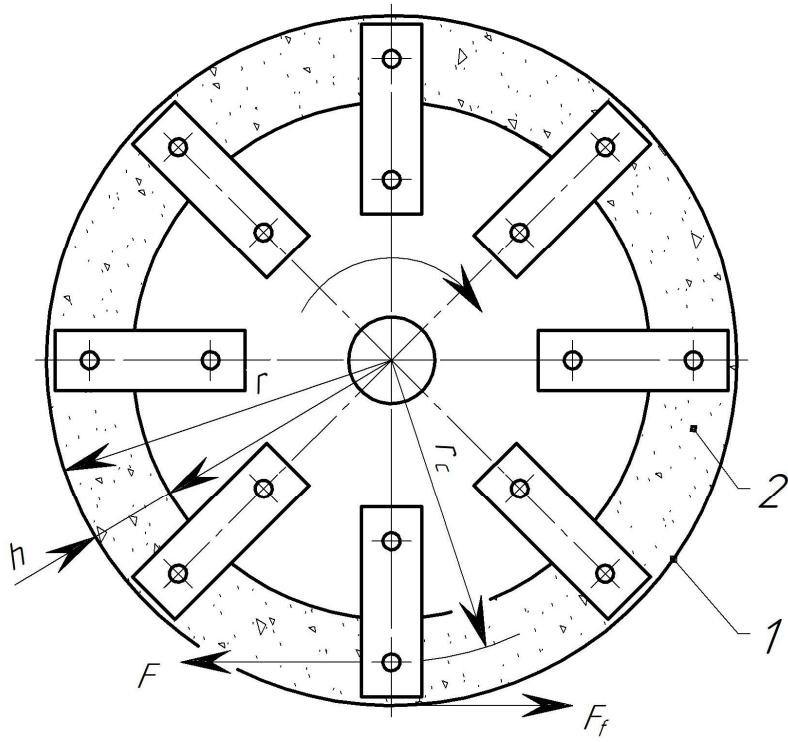

1 - камера молоткової дробарки; 2 - подрібнювальний матеріал

Рисунок 1 - Схема сил, що виникають при подрібненні матеріалу в циліндричній камері

При русі шару по циліндричній поверхні радіусом $r$ виникає сила тертя:

$$
E_{f}=F_{c} f_{m}=m \frac{V_{s}^{2}}{r_{c}} f_{m},
$$

Де $F_{c}$ - центробіжна сила шару, $\mathrm{H} ; f_{m}$ - коефіцієнт тертя шару о циліндричну поверхню; $m$ - маса шару, кг; $r_{c}$ - середній радіус шару, м. 
В силу тертя включені всі сили, що гальмують рух шару. Припустимо, що на шар діють тільки сили $F$ і $F_{f}$; подрібнювальний матеріалрозподіляється рівномірно по всій циліндричній поверхні робочої камери; властивості його виражаються через коефіцієнти тертя і опору, не залежать від кількості матеріалу; сили дії молотків прикладена у всіх точках шару.

Рух шару описується диференціальним рівнянням:

$$
m \frac{d V_{s}}{d t}=F-F_{f}
$$

або

$$
m \frac{d V_{c}}{d t}=\varepsilon S_{p} \rho \frac{\left(V_{p}-V_{s}\right)^{2}}{2}-m \frac{V_{s}^{2}}{r_{c}} f_{m} .
$$

Фізичний сенс цього рівняння можна представити наступним чином. На початку шар матеріалу і молотки нерухомі. При початку руху молотків зі швидкістю сила, з якою матеріал опирається ї переміщенню, діє на шар і рухає його. Зі збільшенням швидкості шару рушійна сила зменшується внаслідок скорочення різниці швидкостей молотків і шару, а в той же час виникає сила тертя, яка зростає зі збільшенням швидкості останнього. Шар буде переміщуватися зі швидкістю, яка залежить від суми вказаних сил.

Розв'язав рівняння (4), отримаємо:

$$
V_{s}=V_{p} \frac{1}{1+\psi} \cdot \frac{1-\exp \left(-2 V_{p} \frac{f_{m}}{r_{c} \psi} t\right)}{1-\frac{1-\psi}{1+\psi} \exp \left(-2 V_{p} \frac{f_{m}}{r_{c} \psi} t\right)},
$$

де

$$
\psi=\sqrt{\frac{2 V f_{m}}{S_{p} r_{c} \varepsilon}} .
$$

Перетворимо вираз (6), виразимо об'єм шару $V$ через його розміри і радіус циліндричної поверхні $r_{c}$ :

$$
\begin{gathered}
V=\pi b h(2 r-h)=\pi S_{s}(2 r-h), \\
r_{c}=r-\frac{h}{2},
\end{gathered}
$$

де $\quad b$ - ширина шару, тобто робочої камери, м;

$h$ - висота шару, м;

$r$ - радіус шару, тобто робочої камери, м.

$S_{s}$ - площа його поперечного перетину, $\mathrm{M}^{2}$.

Підставимо значення з формул (7) і (8) в вираз (6) і отримаємо:

$$
\psi=2 \sqrt{\pi} \cdot \sqrt{\frac{S_{s}}{S_{p}} \cdot \frac{f_{m}}{\varepsilon}} .
$$

Перша частина підкореневого виразу формули (9) - відношення площ перетину шару i лобової частини молотків, занурених в шар; друга - відношення коефіцієнтів. Характерно, що в обох випадках чисельники відносяться до нерухомої частини подрібнювального апарату, а знаменники до рухомої. Оскільки від величини $\psi$ залежить швидкість шару, назвемо ії коефіцієнтом швидкості. 3 рівняння (5)

$$
\lim _{t \rightarrow \infty} V_{s}=V_{p} \frac{1}{1+\psi} .
$$


Тобто отримуємо граничне значення швидкості шару при визначенні швидкості молотків. 3 виразу (10) слідує, що швидкості шару і молотків пов'язані прямолінійною залежністю.

\section{Висновки}

Для конкретній дробарки, в якій колова швидкість молотків стала, швидкість шару залежить від властивостей матеріалу, виражених коефіцієнтами тертя та опору для даних умов. Отримані залежності середньої швидкості шару подрібнювального матеріалу від швидкості молотків дробарки можуть бути застосовані при визначенні конструктивно-технологічних параметрів молоткових дробарок.

\section{ЛITEPАТУРА}

1. ГОСТ 7090-72. Дробилки молотковые однороторные. Технические условия. - Москва: Государственный комитет СССР по стандартам, 1989. - 14 с.

2. Андреев С.Е., Перов В.А., Зверевич В.В. Дробление, измельчение и грохочение полезных ископаемых [Текст] / 3-е изд., перераб. и доп. М.: Недра, 1980. - 415 с.

3. Баренблатт Г.И. О некоторых общих представлениях математической теории хрупкого разрушения [Текст] // ПММ. - 1964. - № 4. -С. 630-643.

4. Ходаков Г.С. Физика измельчения [Текст] / Г.С.Ходаков - М.: Наука, 1972. -307 с.

5. Васильченко Т.О., Шевченко І.А., Кобрін Ю.Г. Аналіз руйнування крихких матеріалів ударом [Текст] / Металургія. Наукові праці запорізької державної інженерної академії. Запоріжжя: ЗДІА.- 2017. - Вип. 2(38). - С.116-122.

6. Качанов Л.М. Основы механики разрушения. [Текст] / - М.: Наука, 1974. - 312 с.

7. Левченко, О.О. Проблемы дробления и моделирования процесса дробления горячего агломерата [Текст] / О.О. Левченко // Сборник научных трудов Донбасского горнометаллургического института. - Алчевск : ДонГМИ, 2004. - Вып. 18. - С. 178-186.

\section{REFERENCES}

1. GOST 7090-72. Drobilki molotkovyie odnorotornyie. Tehnicheskie usloviya. - Moskva: Gosudarstvennyiy komitet SSSR po standartam, 1989. - $14 \mathrm{~s}$.

2. Andreev S.E., Perov V.A., Zverevich V.V. Droblenie, izmelchenie i

grohochenie poleznyih iskopaemyih [Tekst] / 3-e izd., pererab. i dop. M.: Nedra, 1980. - $415 \mathrm{~s}$.

3. Barenblatt G.I. O nekotoryih obschih predstavleniyah matematicheskoy teorii hrupkogo razrusheniya [Tekst] // PMM. - 1964. - \# 4. -S. 630-643.

4. Hodakov G.S. Fizika izmelcheniya [Tekst] / G.S.Hodakov - M.: Nauka, 1972. -307 s.

5. Vasilchenko T.O., Shevchenko I.A., KobrIn Yu.G. AnalIz ruynuvannya krihkih materIalIv udarom [Tekst] / MetalurgIya. NaukovI pratsI zaporIzkoYi derzhavnoYi InzhenernoYi akademIYi. ZaporIzhzhya: ZDIA.- 2017. Vip. 2(38). - S.116-122.

6. Kachanov L.M. Osnovyi mehaniki razrusheniya. [Tekst] / - M.: Nauka, 1974. - 312 s.

7. Levchenko, O.O. Problemyi drobleniya i modelirovaniya protsessa drobleniya goryachego aglomerata [Tekst] / O.O. Levchenko // Sbornik nauchnyih trudov Donbasskogo gorno-metallurgicheskogo instituta. - Alchevsk : DonGMI, 2004. - Vyip. 18. - S. 178-186.

Received 22.01.18

\section{DETERMINATION OF VELOCITY OF LAYER OF MATERIAL IS IN HAMMER CRUSHER}

Grinding workflows are used in various industries. Depending on the quality and properties of the material, the processing processes are carried out by a crushing machine of various designs. Impact crushers are widespread among them. For grinding fragile materials, with the formation of a product-air layer, hammer crushers are used. This is explained by the fact that the hammers reeling 
around the axes of the suspension change their relative speed, direction and depth of immersion in the product-air medium, which disrupts its uniform movement. The task of the study is to find the dependence of the average speed of a layer of comminuted material on the speed of hammers - one of the main parameters of a hammer crusher. The processes of breakage of fragile materials shallow are examined, with formation of product-air layer, by the crushers of shock action in that efficiency of destruction of particles depends mainly on their velocity in relation to hammers and immobile surface of working chamber. Theoretical studies are undertaken is a search of dependence of middle velocity of layer of the ground down material from velocity of hammers - one of basic parameters of hammer crusher. Dependences of middle velocity of layer of the ground down material are got on velocity of hammers of crusher that can be applied at determination of structurally-technological parameters of hammer crushers.

Keywords: blow, destruction, velocity.

\section{ОПРЕДЕЛЕНИЕ СКОРОСТИ СЛОЯ МАТЕРИАЛА В МОЛОТКОВОЙ ДРОБИЛКЕ}

Рабочие процессы измельчения используются в различных отраслях производства. В зависимости от качества и свойств материала, процессы обработки осуществляются дробильная машина разнообразных конструкций. Среди них широкое распространение получили дробилки ударного действия. Для измельчения хрупких материалов, с образованием продуктово-воздушного слоя, используются молотковые дробилки. Это объясняется тем, что молотки шатаясь вокруг осей подвеса меняют свою относительную скорость, направление и глубину погружения в продуктово-воздушной среде, что нарушает его равномерное движение. Задача исследования - найти зависимость средней скорости слоя измельчаемого материала от скорости молотков - одного из основных параметров молотковой дробилки. Рассматриваются процессы измельчения хрупких материалов, с образованием продуктово-воздушного слоя, дробилками ударного действия в которых эффективность разрушения частиц зависит в основном от их скорости относительно молотков и неподвижной поверхности рабочей камеры. Проведены теоретические исследования - поиск зависимости средней скорости слоя измельчаемого материала от скорости молотков - одного из основных параметров молотковой дробилки. Получены зависимости средней скорости слоя измельчаемого материала от скорости молотков дробилки которые могут быть применены при определении конструктивно-технологических параметров молотковых дробилок.

Ключевые слова: удар, разрушение, скорость.

Кобрін Юрій Григорович - аспірант, Національна металургійна академія України.

Kobrin Yuriy - postgraduate student, National Metallurgical Academy of Ukraine.

Шевченко Ірина Артурівна - к.т.н., доцент, кафедра металургійного обладнання, Запорізька державна інженерна академіїя.

Shevchenko Irina - Candidate of Technical Sciences, Associate Professor, Department of Metallurgical Equipment, Zaporizhzhya State Engineering Academy.

Кононов Дмитрий Александрович - к.т.н., доцент, кафедра машин и агрегатов металлургического производства, Национальная металлургическая академия Украины.

Kononov Dmitry - Candidate of Technical Sciences, Associate Professor, Department of Machines and Aggregates of Metallurgical Production, National Metallurgical Academy of Ukraine.

Васильченко Тетяна Олександрівна - к.т.н., кафедра металургійного обладнання, Запорізька державна інженерна академія.

Vasilchenko Tetyana - Ph.D., Department of Metallurgical Equipment, Zaporizhzhya State Engineering Academy.

Гречаний Олексій Миколайович - аспірант, кафедра машин і агрегатів металургійного виробництва, Національна металургійна академія України.

Grecian Alexey - Postgraduate Student, Department of Machines and Aggregates of Metallurgical Production, National Metallurgical Academy of Ukraine. 